\title{
ARE POLISH HEIS ON THE WAY TO THE THIRD GENERATION UNIVERSITY?
}

\author{
Agnieszka Piotrowska-Piątek* ำ http://orcid.org/0000-0002-6620-5485
}

\begin{abstract}
Background. This article discusses the issue of institutional and quantitative changes in the higher education (HE) in Poland after 1990. It is actual and important issue, widely discussed in public space as well as in literature of the subject.
\end{abstract}

Research aims. The aim of the article is to consider the changes of the model of a higher education institutions (HEIs) have undergone and attempt of evaluation whether this model has evolving towards the university of the third generation. Characteristic features of this model include diversification of finance sources and growing relations of a HEI with its environment, both in educational and research terms. That is why the Author consider these two areas of HEIs' activity.

Methodology. To reach research aims, an analysis of legal sources, the literature of the subject and desk top research have been carried out, the latter drawing on the data of Statistics Poland, among other sources.

Key findings. The analysis shows the period in question has seen the model of a HEI evolving towards the university of the third generation.

Keywords: higher education in Poland, higher education institutions, management of HEI, model of third generation university

JEL Codes: J21, D22

\section{INTRODUCTION}

The system of higher education (HE) constitutes a group of institutions that have been established to provide university level education and to regulate the internal and external academic governance in a given country (Piotrowska-Piątek, 2018, p. 37). In Poland, this system is among the most dynamically developing fields of the social life and it

*Kielce University of Technology, Statistical Office in Kielce. E-mail: apiotrowskapiatek@ gmail.com 
has undergone considerable quantitative and institutional changes since the beginning of the 1990s. The political system transformation and the European integration that followed created new conditions for this system. The transformation process that started then has extended over many years and has encompassed various aspects of higher education institutions (HEIs), starting from attempts to redefine their identity in the 'great transformation' context to seeking new organizational solutions (Dybaś et al., 2011, p. 121).

The aim of the article is to consider the changes of the model of HEIs have undergone and attempt of evaluation whether this model has evolving towards the university of the third generation. To do this, an analysis of legal sources, the literature of the subject and desk top research have been carried out, the latter drawing on the data of Statistics Poland, among other sources. The article uses terms of 'a higher education institution' and 'a university' interchangeably.

\section{POLISH HIGHER EDUCATION MODEL IN TRANSITION AFTER 1990}

In order to define the key concept informing this paper, i.e. the concept of 'the HE model', the Author refers to organization, structure (i.e. distribution of specific school types as well as organizational and ownership connections), the ways this system is financed, and especially to the relations between the main players: the state (in its institutional capacity) and its agencies on the one side and HEIs on the other. Referring to opinions of other authors, Thieme, well known for his research on $\mathrm{HE}$, defines the model of $\mathrm{HE}$ as a simplified and idealized description of existing or suggested solutions within such areas as social preferences, relations between HEIs and state authorities, the role of market; a description that should cover all formal and practical mechanisms as well as relations at a university-ministry level. Such a model should take into consideration main 'actors on a HE stage', i.e. state, regional and local authorities, students, academic staff, university management, national and regional markets, international and global markets as well as transnational networks (Thieme, 2009, p. 45).

Clark's triangle of coordination is one of the best known organizational models of HE (1983). HE systems can be coordinated by the state (bureaucratic model), market (market model) or academic oligarchy: 
corporation of professors (academic oligarchy model). These three factors determine the extent of university autonomy, thus mapping out both the space in which universities function and regulation mechanisms. According to Thieme's estimation of the Polish HE system, from the perspective of Clark's model, there is a mixed system in Poland at present. In the public sector, the solutions are closer to the academic oligarchy model while the private sector is closer to the market model, with a somewhat higher degree of state regulation of this sector (Thieme, 2009, p. 45). The Author is on the same page.

Until 1989, the Polish HE system had been fully regulated by the state. The Higher Education Act of 12 September 1990 put an end to a long period of the state monopoly by enabling deregulation processes and making it possible for individuals and legal persons to set up private HEIs (having been granted permission of the Minister of Higher Education, subject to a favourable opinion of the Chief Council of Higher Education). In the Act of 1990, the legislator stated that HEIs are part of the Polish science and national education systems and they were given discretion in academic research, artistic work and education (Act of 12 September 1990 o szkolnictwie wyższym). The Minister of National Education was responsible for HE, and the Chief Council of Higher Education was a representative body of HE.

Indisputably, the rise of private HEIs and thus diversification of the HE system is considered to be among the most important institutional-quantitative transformations of the Polish HE that followed the political transformation of the country (cf.: Wnuk-Lipińska, 1996, pp. 37-39). Kwiek, well known for his research on HE, claims that the rise of private $\mathrm{HE}$ in Poland was in no way 'designed': it occurred as a natural response to a strong social need and a powerful financial motivation of the academic staff, whose financial standards declined in the 1990s (Kwiek, 2015, p. 117). The research on HE in Europe shows that the private sector appeared in countries where educational aspirations of young people increased dramatically and the public sector was not able to finance this growth in the number of students from public funds (Kwiek, 2010, p. 103). The figures speak for themselves: the total number of graduates of private/non-public HEIs from 1993 to 2016 amounted to over two million people (Graph 1). 


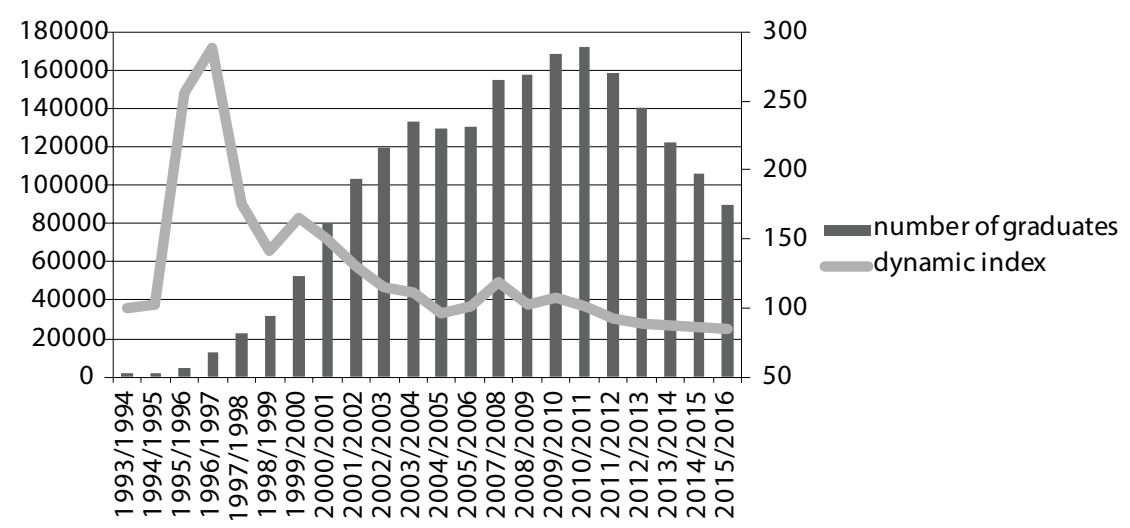

Graph 1. The number of graduates of non-public HEIs in Poland and the dynamics of change (chain index) from 1993/94 to 2015/16

Source: the Author's calculations and elaboration on the data of the Centre of Education and Human Resources Statistics, Statistics Office in Gdańsk.

Researchers greatly differ in their opinions of the effects of the liberalisation of the educational market in the 1990s: some highly appreciate the contribution of the private sector into development of $\mathrm{HE}$ and social and economic growth of regions; others are strongly critical and question the legitimacy of deregulating the system.

A further important stage of institutional changes occurred in 1997, when a new type of HEI: state vocational higher institutions were introduced. The establishment of this type of schools was due to practical reasons (in order to satisfy needs of labour market) and social considerations - opening up an educational path to people with limited financial means who live in smaller towns and villages (Pawłowski \& Graszewicz, 2014). Some experts in this field link the appearance of such schools to the national administration reform of 1999, as a result of which a number of cities lost their the voivodship centre status. Accordingly, state vocational higher education schools were meant to recompense this loss in status (cf.: Podwójcic, 2017, p. 67).

As can be seen, over the first 15 years of the political system transformation, we witnessed an expansive development of $\mathrm{HE}$ and co-existence of public and private sector. The next stage, starting with legislative changes at the beginning of the first decade of the 
$21^{\text {st }}$ century, involved attempts to increase the controlling function of the state by such steps as creating the State (now changed to Polish) Accreditation Committee and raising requirements to be met to enter the HE market (cf.: Ratajczak, 2012, p. 54).

Since 2005, we have been observing changes adapting the system of $\mathrm{HE}$ in Poland to European standards (the so-called Bologna Process as an effect of Poland joining the European Union) through inter alia introduction of three-tier education. A milestone in these changes occurred in 2011, since when there has been an ongoing reorientation of the philosophy of education, from education programs based on the standards of education (adjustment mechanism for education programs based on precisely defined program minimums, set up by the legislature) towards education orientated to learning outcomes. This meant extending HEIs' autonomy when it comes to designing academic curricula. These changes have been accompanied by institutional changes that concern extending opportunities for HEIs to exercise discretion over their internal governance, irrespective of their type. However, these changes also entailed a considerable increase in administrative responsibilities of HEIs: extended internal and external (to government institutions) reporting. At the same time, in terms of the structure of HE market we can see a decline in the number of schools and organizational and capital transformations, especially consolidation processes.

The latest reform programme initiated in 2016 is intended, according to the government institutions that are preparing it, to address the unfavourable processes that have been seen for some time, such as a decline in Poland's academic rating and status internationally, a decline in the quality of academic education due to its mass scale, bureaucracy of the system, improper allocation of inadequate funds, a decline in a social and financial status of academic staff. At the time of this article being written, definitive legislative solutions of so-called Act 2.0 are not yet known.

\section{QUANTITATIVE DIMENSION OF POLISH HIGHER EDUCATION DEVELOPMENT}

While analysing the changes in the HE system, it is necessary to consider the statistics that illustrate the quantitative scope of the 
changes. According to official statistics, there were 112 HEIs in Poland in the 1990/1991 academic year. The first private HEI was established, pursuant to the Act of 1990, a year later. At that time, heightened educational aspirations of young people overlapped with needs for qualified labour, due to the restructuring economy, as well as with the demographic boom in the 1990s. When it comes to HE, demographic trends are of key importance for the system. The number of people in Poland nominally attributed to the age of being in HE (19-24) was increasing from 1990 up to 2004, which contributed to the positive dynamics of change both in terms of the number of HEIs (Graph 2) and the number of students (Graph 3).

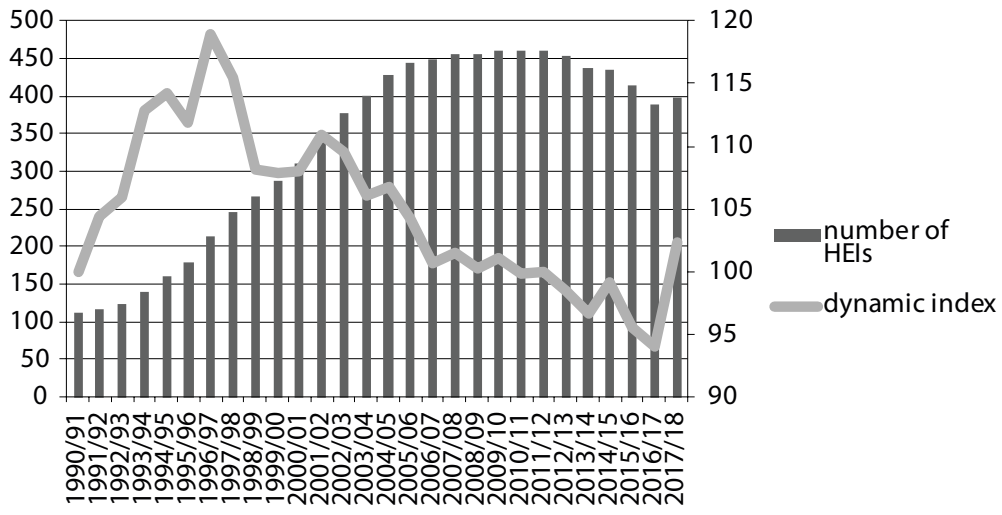

Graph 2. The number of HEIs in Poland and the dynamic of change (chain index) from 1990/1991 to 2017/2018

Source: the Author's calculations and elaboration on the data of the Centre of Education and Human Resources Statistics, Statistics Office in Gdańsk and Główny Urząd Statystyczny, 2018, p. 212.

Over the last few years, this dynamics has slowed down noticeably. In the first place, this is due to the decline in the birth rate whose impact on the educational system is referred to as 'a demographic tsunami' (indirectly, the condition and structure of $\mathrm{HE}$ are also affected by a general demographic context), as well as to declining capacity of the state to finance science and $\mathrm{HE}$ and to the challenges posed to the educational process by the labour market in knowledge-based economy. 


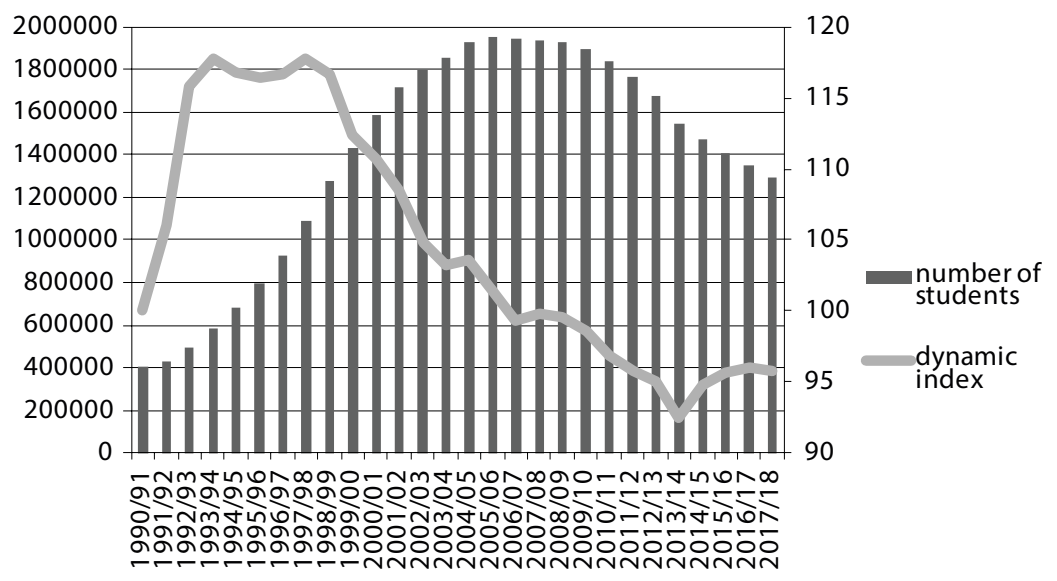

Graph 3. The number of students in Poland and the dynamic of change (chain index) from 1990/1991 to 2017/2018

Source: the Author's calculations and elaboration on the data of the Centre of Education and Human Resources Statistics, Statistics Office in Gdańsk and Główny Urząd Statystyczny, 2018, p. 213.

\section{ORGANIZATIONAL AND CAPITAL CHANGES IN THE STRUCTURE OF EDUCATIONAL MARKET}

Assessments of the number of HEIs in Poland, both in absolute and relative (in comparison to the population of Poland or other European countries of a similar number of inhabitants) terms are unequivocally negative (cf.: Rada Główna Nauki i Szkolnictwa Wyższego, 2017, p. 6). There are too many schools, especially in the private sector. After the time of the state and private sectors co-existing with each other and a high dynamics of new schools being established, we witness organizational and capital changes towards streamlining the structures of both sectors, through consolidation (school takeovers on a regional scale) as well as through school unions (so-called private educational systems).

In contrast to some other $\mathrm{HE}$ systems, consolidation processes in Poland were not so much of system reform nature as a result of grassroots initiatives and market pressure. In various countries, relations between state authorities and entities to be consolidated were based 
on one of the following approaches (Rada Główna Nauki i Szkolnictwa Wyższego, 2017, p. 12):

- 'don't disturb', which involves providing conditions for organic occurrence of a result desired, through a normative system of institutional incentives whereby 'together' means better than 'alone' (it is established that this approach is the most effective, Flanders, France, Denmark, Estonia, Finland and Ireland being a case in point);

- 'passive approach', whereby legal infrastructure enables consolidation with a chance of financial support, but there are no long-term incentives as a consolidation process itself does not change the way of financing;

- 'political imperative', whereby a normative law concerning consolidation of specified entities is introduced.

In Poland an essential role in the processes occurring in both state and private HEIs is played by legal determinants, which are factors of key importance, and by financial factors. There are significant differences between consolidations in the public and private sectors. Predominantly, the public sector underwent consolidation from 1998 to 2004. The majority of consolidation processes led to combining schools to create a HEI of a higher status, that of a university in most cases. For instance, the University of Warmia and Mazury in Olsztyn was established in 1999 by merging three existing schools: The Higher School of Pedagogy, The Academy of Agriculture and Technology, and the Warmian Theological Institute. After 2009, consolidation processes in public schools mainly concerned incorporating in their structures foreign language and teacher training colleges, which were then in the process of liquidation. In turn, consolidation of private schools have been taking place since 2000 , but they occurred very rarely until 2006. The private sector has seen consolidation processes on a bigger scale since 2017 , i.e. since demographic problems started. In total, the period from 2001 and 2014 saw almost 70 takeovers of private HEIs, and the majority of them concerned single schools consolidated in the structures of private university systems. If we compare consolidation processes in these two sectors of HE in Poland, essential differences between them can be identified in terms of reasons for consolidation, its intensity and time of occurrence. The private sector responded much earlier to the unfavourable demographic changes discussed above while in public schools consolidation processes motivated by this reason have 
not occurred as yet. The differences also concern the reasons for making decisions of consolidation, as well as forms and ways of consolidation. Public HEIs consolidate in order to enhance their academic strength and school's status, while in the case of private schools it is economic considerations (e.g. avoiding bankruptcy) already occurring or forecast by their founders that inform consolidation actions (Zygarłowski, 2015, pp. $87,91,93)$. In private HE consolidation predominantly takes a traditional form whereby former competitors take over control of their competition. This process is accelerating, and is leading to changes in the structure of this market from dispersed to oligopolistic, with a smaller number of strong players. Such takeovers are performed mainly to achieve financial goals rather than reaching synergy in the academic substance (Łobos \& Szewczyk, 2015, p. 49).

Private-state consolidations are a rarity in Poland so far, with probably the only case of such a consolidation: the Hanseatic Higher School of Management taken over by the Pomorska Academy in Słupsk in 2016 (following liquidation procedure due to legal restrictions).

Another dimension of consolidation processes is marked by socalled private university systems which appeared after 2005, with schools-members of the Higher Schools of Banking group, founded by the Centre of Higher Schools Development, Banking Education Association Academia serving as an example of such consolidation processes. Zygarłowski uses the term of private university systems to define a group of private HEIs which have the same founder/founders, are controlled directly or indirectly by the same individual or legal person who can take decisions or coordinate the operations of schools-members of a group. According to Zygarłowski, of 19 such systems existing in 2014, seven systems grew organically, i.e. by setting up new HEIs by the same founder; five systems developed exclusively through consolidation, i.e. through taking control over already existing schools, and seven systems used a mixed model of development (Zygarłowski, 2015, pp. 123-125).

It seems that both agencies responsible for public policy in $\mathrm{HE}$ (J. Gowin's statement, 22.06.2017) and those managing HEIs (Rada Główna Nauki i Szkolnictwa Wyższego, 2017, p. 12) agree on the need of further streamlining infrastructural and human resources of HEIs. 


\section{TRANSFORMATIONS IN THE MODEL OF A HIGHER EDUCATION INSTITUTION}

By observing and analysing processes that occur in the environment of HEIs (at the level of national and European public policies and in terms of expectations held by various stakeholders) and changes on organization, ways of financing, structure and strategies of managing HEIs, it is possible to state that over the period analysed here Poland has seen the model of the HEI evolving. The model of HE, by mapping out a framework of external and internal academic governance, determines the aims and activities of HEIs. Accordingly, the Author perceives the concept of a university model in the following way, taken as a whole:

- academic commitments of a HEI: its essence (mission and aims),

- relations between the fundamental areas of its activity,

- relations with its environment,

- its internal organization.

Table 1 presents a synthetic comparison of universities of the second and third generations. The literature on the subject follows a heated discussion on the direction and pace of this evolution, as well as on its legitimacy (which, in the Author's opinion, refers to blaming the model of a university of the third generation for unfavourable processes that can be seen in HE, especially a decline in the quality of education and dependence of HEIs on various groups of market stakeholders).

Table 1. Comparison of the second generation model (based on W. Humboldt University) and the third generation model (based on the model of an entrepreneurial university)

\begin{tabular}{|c|c|c|}
\hline Feature & $\begin{array}{c}\text { Model of Humboldt Univer- } \\
\text { sity }\end{array}$ & $\begin{array}{c}\text { Model of entrepreneurial } \\
\text { university }\end{array}$ \\
\hline $\begin{array}{c}\text { Mission and essence of } \\
\text { existence }\end{array}$ & $\begin{array}{c}\text { Spreading thorough knowledge } \\
\text { while maintaining elitism of } \\
\text { education; unity of research } \\
\text { and education; community } \\
\text { of professors and students; } \\
\text { discovery of truth; guarantee } \\
\text { of freedom for research and } \\
\text { education. }\end{array}$ & $\begin{array}{c}\text { Education for labour } \\
\text { markets needs in mass edu- } \\
\text { cation conditions; interdis- } \\
\text { ciplinary research; transfer } \\
\text { of knowledge to the environ- } \\
\text { ment; getting involved in } \\
\text { developmental processes of } \\
\text { societies; a significant role of } \\
\text { the third mission. }\end{array}$ \\
\hline $\begin{array}{c}\text { Role of university in } \\
\text { public order }\end{array}$ & $\begin{array}{c}\text { Element of national, three-tier } \\
\text { education system. }\end{array}$ & $\begin{array}{c}\text { Element of national and } \\
\text { regional systems of innova- } \\
\text { tion and social and economic } \\
\text { development. }\end{array}$ \\
\hline
\end{tabular}




\begin{tabular}{|c|c|c|}
\hline $\begin{array}{c}\text { Organization and struc- } \\
\text { ture }\end{array}$ & $\begin{array}{c}\text { Autonomy; isolation from } \\
\text { the environment; apart from } \\
\text { departments, the structure } \\
\text { includes laboratories and } \\
\text { research institutes. }\end{array}$ & $\begin{array}{c}\text { A strong management } \\
\text { centre; stakeholders' par- } \\
\text { ticipation in managing a } \\
\text { school; co-existence of strong } \\
\text { organizational units and } \\
\text { research centres; peripheral } \\
\text { segments (e.g. academic } \\
\text { technological parks). }\end{array}$ \\
\hline Source of finance & $\begin{array}{c}\text { Public, school's budget inde- } \\
\text { pendent of the state. }\end{array}$ & $\begin{array}{c}\text { Diversified sources (public, } \\
\text { private, so-called third } \\
\text { stream). }\end{array}$ \\
\hline Relations of environment & Do not occur. & $\begin{array}{c}\text { Intensive, formal and infor- } \\
\text { mal, multi-layered. }\end{array}$ \\
\hline Organizational culture & Partnership of professors and \\
students. & $\begin{array}{c}\text { Corporation type (target-ori- } \\
\text { ented, responsibility and } \\
\text { accountability); considerable } \\
\text { role of grass-roots initia- } \\
\text { tives. }\end{array}$ \\
\hline
\end{tabular}

Source: own elaboration.

The model of third generation school is close to the concept of an entrepreneurial university formulated by Clark in 1998 (Clark, 1998). Clark identifies five features of entrepreneurial universities, including the following:

- development of peripheral segments (i.e. units created mainly with a school or with external stakeholders, necessary to break through traditional divisions between disciplinary fields of knowledge and to develop cooperation with the environment in research, knowledge transfer, contacts with business and alumni, fund-raising, intellectual property protection and continuing education);

- diversification of finance sources (with a decline in public financial outlay in $\mathrm{HE}$, it is necessary to seek finance for research from the third stream, i.e. external partners).

This model has evolved greatly due to the fact that in many European countries there were reductions in funds from the public budget and at the same time HE expanded quantitatively (Wójcicka, 2006, p. 16). This means seeking sources of finance other than those coming from the public budget and from tuition fees (private spendings), hence the need for the third stream revenue. Diversification of sources of finance requires HEIs be active in new ways: to enter individual market partnerships, to apply for public (national and European) funds through competition (grants). This necessitates not only good standards of 
research offer but also competitive prices and organizational efficiency in conducting such projects.

So, let us put a question: Do HEIs in Poland diversify their sources of finance? The answer to it requires analysing changes in the structure of operating revenue of HEIs, and within its framework, a qualitative analysis of revenue from research activities and business activity.

HEIs have revenue from their operating activities (basic and other ones) and financial revenue. The basic operating activity brings revenue from teaching activity, from research activities, and from business activities. Table 2 shows the structure of operating activity revenue in five selected years over the period analysed.

Table 2. Structure of revenue from operating activity in public and non-public HEIs in 1997, 2000, 2005, 2010 and 2015 (in \%)

\begin{tabular}{|c|c|c|c|c|c|}
\hline Year & $\begin{array}{l}\text { Teaching } \\
\text { activity }\end{array}$ & $\begin{array}{l}\text { Research } \\
\text { activity }\end{array}$ & $\begin{array}{l}\text { Separated } \\
\text { economic } \\
\text { activity }\end{array}$ & $\begin{array}{c}\text { Sale of } \\
\text { materials } \\
\text { and goods }\end{array}$ & $\begin{array}{c}\text { Other operating } \\
\text { activity reve- } \\
\text { nues }\end{array}$ \\
\hline \multicolumn{6}{|l|}{1997} \\
\hline public & 80.4 & 14.7 & 0.8 & 0.3 & 3.0 \\
\hline non-public & 94.9 & 0.0 & 0.8 & 0.4 & 3.9 \\
\hline \multicolumn{6}{|l|}{2000} \\
\hline public & 79.7 & 15.8 & 0.5 & 0.3 & 2.8 \\
\hline non-public & 96.1 & 0.2 & 0.3 & 0.1 & 3.1 \\
\hline \multicolumn{6}{|l|}{2005} \\
\hline public & 83.3 & 11.4 & 0.7 & 0.2 & 3.8 \\
\hline non-public & 94.6 & 0.7 & 0.6 & 0.2 & 4.0 \\
\hline \multicolumn{6}{|l|}{2010} \\
\hline public & 78.5 & 15.9 & 0.6 & 0.1 & 4.4 \\
\hline non-public & 90.2 & 2.8 & 0.3 & 0.3 & 6.3 \\
\hline \multicolumn{6}{|l|}{2015} \\
\hline public & 77.3 & 14.9 & 0.5 & 0.1 & 6.8 \\
\hline non-public & 85.7 & 4.4 & 0.7 & 0.3 & 8.9 \\
\hline
\end{tabular}

Source: prepared by the Author on the basis of: Główny Urząd Statystyczny, 1998, p. 416; Główny Urząd Statystyczny, 2001, p. 446; Główny Urząd Statystyczny, 2006, p. 310; Główny Urząd Statystyczny, 2011, p. 342; Główny Urząd Statystyczny, 2016, p. 190.

In both types of HEIs, it is possible to see a decreasing share of revenue from teaching activity and an increasing share of revenue coming from research activity, and the scale of these changes is more noticeable in non-public HEIs. 

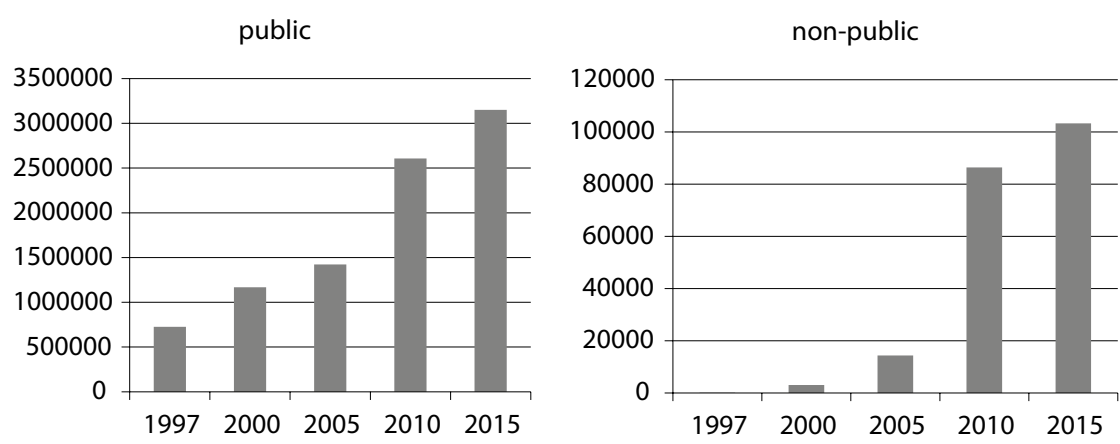

Graph 4. Revenue from research activities in public and non-public HEIs in 1997, 2000, 2005, 2010, 2015 (in thousands of PLN)

Source: prepared by the Author on the basis of: Główny Urząd Statystyczny, 1998, p. 414; Główny Urząd Statystyczny, 2001, p. 445; Główny Urząd Statystyczny, 2006, p. 309; Główny Urząd Statystyczny, 2011, p. 340; Główny Urząd Statystyczny, 2016, p. 188.

Let us analyse qualitatively changes in revenue from research activity (Graph 4). There is a considerable and obvious (given the functions and research potential) difference in the scale of revenue generated. In the period analysed, there is a noticeable high and positive dynamics of change in the category analysed. Having said that, it is necessary to remember that up to 2010 it was to a large extent due to an increasing number of HEIs, especially in the case of private HEIs.

Given the aim of this article, revenue from sale of other research and development projects and services is an especially essential category of revenue from research activity (Graph 5). This includes revenue from sales according to contracts concluded with domestic and foreign business entities, private individuals or other entities. Here, we also note an increase in revenue, with a much higher dynamic of change in private HEIs.

HEIs cooperate with their social and economic environment within the regulations of the Higher Education Law (Act of 27 July 2005 Higher Education Law). This cooperation involves conducting R\&D activities for business and the form and scope of such activities are regulated by a HEI statute. Art. 7 of the Law provides for HEI to be able to conduct business activity, especially in the form of limited 

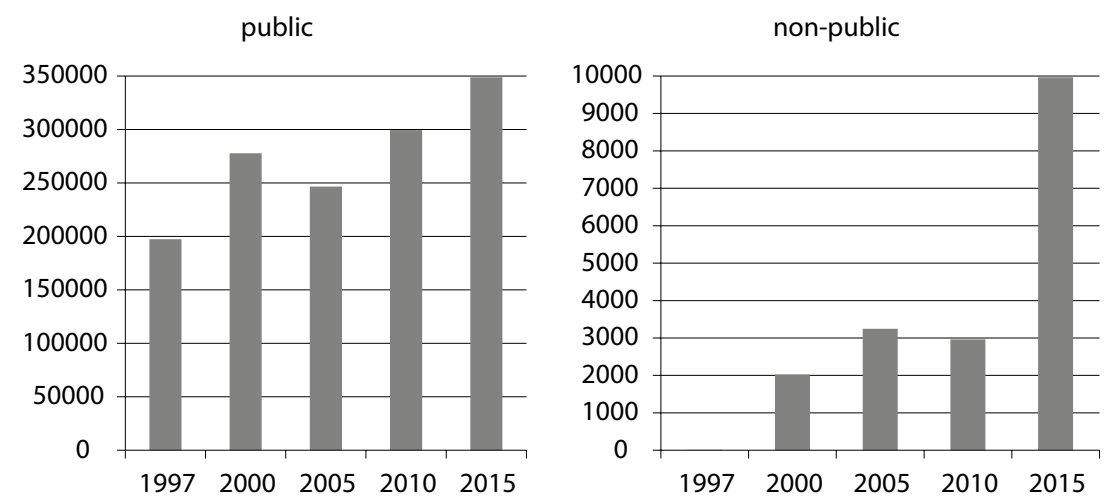

Graph 5. Revenue from sale of other research and development projects and services in public and non-public HEIs in 1997, 2000, 2005, 2010, 2015 (in thousands of PLN)

Source: prepared by the Author on the basis of: Główny Urząd Statystyczny, 1998, p. 422; Główny Urząd Statystyczny, 2001, p. 449; Główny Urząd Statystyczny, 2006, p. 314; Główny Urząd Statystyczny, 2011, p. 349; Główny Urząd Statystyczny, 2016, p. 197.

companies (e.g. technology transfer centres). Such activities should be isolated organizationally and financially from running canteens and halls of residence as well as those activities that are enumerated in Art. 13 of the Law (HEI basic commitments). The analysis of this category of revenue shows that over the period analysed the largest share of public HEIs revenue was generated by agricultural, medical and technical schools while in the case of private HEIs the largest share was generated by schools of economic profile. While a qualitative analysis of the period analysed shows fluctuations, from 2010 (i.e. in the period of a decrease in the number of HEIs) there has been an increase in this type of revenue (Graph 6).

An entrepreneurial university is oriented towards its environment. Such an orientation is performed by creating and developing peripheral segments mentioned above, which are often referred to as bridge institutions that operate either within a university, at the contact point with the environment, or outside a university. This 'contact point' is best illustrated by Pierzynowski, who described his professional experience at a university and in a technological park in the following way: "in practice, I do know myself where the university ends, and 

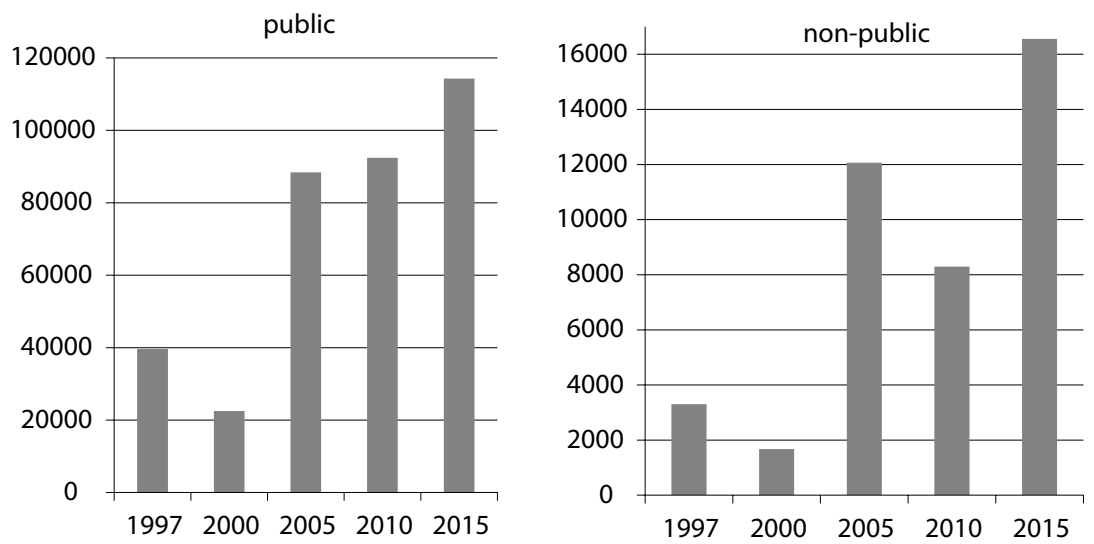

Graph 6. Revenue from separated economic activity in public and non-public HEIs in 1997, 2000, 2005, 2010, 2015 (in thousands of PLN)

Source: prepared by the Author on the basis of: Główny Urząd Statystyczny, 1998, p. 414; Główny Urząd Statystyczny, 2001, p. 445; Główny Urząd Statystyczny, 2006, p. 309; Główny Urząd Statystyczny, 2011, p. 340; Główny Urząd Statystyczny, 2016, p. 200.

where the industry begins" (Pierzynowski, 2004, p. 26). Among such segments, called sometimes bridge organizations, there are convents, stakeholders' councils, academic centres of continuing education, open universities, technology transfer centres, academic incubators of entrepreneurship, spin-offs, external ambassadors. Selected examples of such institutions in the Polish HE, namely convents and academic incubators of entrepreneurship are presented below.

An institution of a convent as entity permanently present in a HEI structure was introduced by Act of Vocational Higher Education Schools of 26 June 1997 (within which such schools operated until the Law of 27 July 2005 was passed) as an obligatory collegial body for this type of schools. At present, in the light of the current legislation, a convent is a collegial body which is obligatory for the structures of public vocational schools, while public academic HEIs exercise discretion in this respect. In the case of private HEIs, the law does not require creating collegial organs other than a senate. Ways of appointing a convent, its exact composition and its competencies are regulated by a HEI statute. The Act amendment of 2016 simplified regulations concerning a convent membership and maintained its bridging character 
in relations between a university and its environment. The results of the Author's study carried out in 2015 show that a convent was present in almost all the public vocational schools that were analysed (94.4\%), in the majority of private HEIs and public academic HEIs (86.3\% and 67.7\% respectively) (Piotrowska-Piatek, 2018, pp. 236-241). The bill of a new higher education law (so called Act 2.0) that is being proceeded at present aims to introduce an institution of a HEI council with strong management powers, over $50 \%$ of whose members will be those outside a HEI.

Academic incubators of entrepreneurship are another example of bridging organizations. In the light of the current legal regulations, they are established to support business activities of academic staff, other employees of a university as well as students. They are set up as a university-wide organizational unit or a limited company (Act of 27 July 2005 Prawo o szkolnictwie wyższym, art. 86.2 and 3). They started to be established after 1990 and it is widely accepted that the first attempt at creating an academic incubator of entrepreneurship was made at Warsaw University in 1998, by setting up a programme of pre-incubation of business ideas of the university students, within the University Centre of Technology Transfer. According to the data of the Polish Agency for Enterprise Development, 62 academic incubators of entrepreneurship were operating in Poland in 2010 (Mażewska et al., 2011, p. 13). Four years later, there were already 74 pre-incubators and academic incubators of entrepreneurship in Poland (data of the Association of Innovation and Entrepreneurship; Bąkowski, 2015, pp. 56-57).

\section{CONCLUSIONS}

This article presents quantitative and institutional aspects of $\mathrm{HE}$ which reflect Poland's HE in its transition in the period from 1990 up to now. However, it must be pointed out that the considerations presented here naturally do not exhaust the whole nature of the problem and they, naturally, reflect the Author's point of view.

The analysis carried out here lets the Author conclude that the model of a HEI in Poland is evolving towards a university of the third generation, whose characteristic features include diversification of 
finance sources and growing relations of a HEI with its environment, both in educational and research terms.

The processes presented are contingent upon a number of various and often co-occurring factors such as demographic changes, challenges posed by economy based on knowledge, national and European public policies, as well strategies of HEIs themselves, since HEIs also create these changes. As a consequence - nowadays HEIs in Poland are under a big permanent challenge: the need of meeting diversified expectations and optimising their resources.

At the end, it should be admitted that the literature on the subject records mixed reactions to these changes: praise, acceptance, understanding of the need for re-orientation of modern HEIs, but also disapproval of such a model. There is not one, acceptable to all researchers, model of HEI nowadays.

\section{REFERENCES}

Bąkowski, A. (2015). Preinkubatory i akademickie inkubatory przedsiębiorczości. In:

A. Bąkowski \& M. Mażewska (eds.). Ośrodki innowacji i przedsiębiorczości w Polsce. Raport 2014. Warszawa-Poznań: Stowarzyszenie Organizatorów Ośrodków Innowacji i Przedsiębiorczości w Polsce.

Clark, B. R. (1998). Creating Entrepreneurial Universities: Organizational Pathways of Transformations. Oxford: Pergamon Press.

Dybaś, M., Dziemianowicz-Bąk, A., Krawczyk-Radwan, M. \& Walczak, D. (2014). Szkolnictwo wyższe. In: Kontynuacja przemian. Raport o stanie edukacji 2011. Warszawa: Instytut Badań Edukacyjnych.

Główny Urząd Statystyczny (1998). Szkoły wyższe i ich finanse w 1997 r. Warszawa: Zakład Wydawnictw Statystycznych.

Główny Urząd Statystyczny (2001). Szkoły wyższe i ich finanse w 2000 r. Warszawa: Zakład Wydawnictw Statystycznych.

Główny Urząd Statystyczny (2006). Szkoły wyższe i ich finanse w 2005 r. Warszawa: Zakład Wydawnictw Statystycznych.

Główny Urząd Statystyczny (2011). Szkoty wyższe i ich finanse w 2010 r. Warszawa: Zakład Wydawnictw Statystycznych.

Główny Urząd Statystyczny (2016). Szkoty wyższe i ich finanse w 2015 r. Warszawa: Zakład Wydawnictw Statystycznych.

Główny Urząd Statystyczny (2018). Mały rocznik statystyczny. Warszawa: Zakład Wydawnictw Statystycznych. 
Kwiek, M. (2010). Transformacje uniwersytetu. Zmiany instytucjonalne $i$ ewolucje polityki edukacyjnej w Europie. Poznań: Wydawnictwo Naukowe Uniwersytetu im. A. Mickiewicza.

Kwiek, M. (2015). Uniwersytet $w$ dobie przemian. Warszawa: Wydawnictwo Naukowe PWN.

Łobos, K. \& Szewczyk, M. (2015). Sieciowe współdziałania niepublicznych szkół wyższych na świecie i w Polsce: realia i perspektywy. In: P. Zygarłowski \& K. Łobos (eds.). Procesy konsolidacji w szkolnictwie wyższym. Stan i perspektywy. Warszawa: CeDeWu.PL.

Mażewska, M., Rabczenko, A. \& Tórz A. (2011). Organizacja i zarzadzanie działalnościq inkubatorów technologicznych. Gdańsk-Warszawa-Poznań: Polska Agencja Rozwoju Przedsiębiorczości.

Pawłowski, A. \& Graszewicz, M. (2014). Zlikwidować lub przekształcić. Analiza sytuacji państwowych wyższych szkół zawodowych. Forum Akademickie, 6. Retrieved from: https://prenumeruj.forumakademickie.pl/fa/2014/06/ zlikwidowac-lub-przeksztalcic/ (access: 22 $2^{\text {nd }}$ June 2017).

Pierzynowski, S. (2004). Park technologiczny IDEON, Lund, Szwecja, tzn. nauka, patenty, ryzyko, pieniądze. In: Uczelnie a innowacyjność gospodarki. Warszawa: Instytut Problemów Współczesnej Cywilizacji.

Piotrowska-Piątek, A. (2018). Wspótpraca z otoczeniem w misjach i strategiach szkót wyższych. Warszawa: CeDeWu.

Podwójcic, K. (2017). Dobra uczelnia - czyli jaka? In: R. Siemieńska (ed.). Uniwersytety, naukowcy i studenci w zglobalizowanym świecie. Warszawa: SCHOLAR.

Rada Główna Nauki i Szkolnictwa Wyższego (2017). Konsolidacja w sektorze szkolnictwa wyższego (ed. J. Szambelańczyk), report 6/2017. Warszawa.

Ratajczak, M. (2012). Zmiany w otoczeniu wyższego szkolnictwa ekonomicznego w Polsce. In: J. Dietl \& Z. Sapijaszka (eds.). Edukacja ekonomiczna wobec przemian otoczenia społeczno-gospodarczego. Łódź: Wydawnictwo Fundacji Edukacyjnej Przedsiębiorczości.

Thieme, J. (2009). Szkolnictwo wyższe. Wyzwania XXI wieku. Polska. Europa. USA. Warszawa: Difin.

Wnuk-Lipińska, E. (1996). Innowacyjność a konserwatyzm. Uczelnie polskie w procesie przemian społecznych. Warszawa: Instytut Studiów Politycznych PAN.

Wójcicka, M. (2006). Uniwersytet i jego otoczenie - dwa sposoby podejścia i ich możliwe konsekwencje. In: K. Leja (ed.). Problemy zarzadzania w uczelni opartej na wiedzy. Gdańsk: Wydawnictwo Politechniki Gdańskiej.

Zygarłowski, P. (2015). Koncentracja, konsolidacja i dekonsolidacja w polskim szkolnictwie wyższym. In: P. Zygarłowski \& K. Łobos (eds.). Procesy konsolidacji w szkolnictwie wyższym. Stan i perspektywy. Warszawa: CeDeWu.PL. 


\section{Other sources}

Act of 12 September 1990 o szkolnictwie wyższym, Dz.U. 1990 No 65, item. 385.

Act of 27 July 2005 Prawo o szkolnictwie wyższym, Dz.U. 2005 No 164, item. 1365, with changes.

J. Gowin's statement: Consolidation of higher education schools and institutes would be in everybody's interest. Retrieved from: http://naukawpolsce.pap.pl/aktualnosci/ news,408046,gowin-konsolidacja-uczelni-i-instytutow-bylaby-w-interesie-wszystkich. html (access: 22.06.2017).

Projekt ustawy Prawo o szkolnictwie wyższym. Retrieved from: http://irsw.pl/wp-content/uploads/Projekt-ustawy-prawo-o-szkolnictwie-wy\%C5\%BCszym-i-nauce-zdnia-22.01.2018.pdf (access: 15.07.2018).

\section{CZY POLSKIE SZKOLNICTWO WYŻSZE ZMIERZA W KIERUNKU MODELU UNIWERSYTETU TRZECIEJ GENERACJI?}

\section{Abstrakt}

Tło badań. W artykule podjęto problem instytucjonalno-ilościowych przemian w szkolnictwie wyższym w Polsce po 1990 roku. Jest to aktualne i ważne zagadnienie, szeroko dyskutowane w przestrzeni publicznej i literaturze przedmiotu.

Cel badań. Celem artykułu jest rozważenie przemian modelu szkoły wyższej oraz próba odpowiedzi na pytanie, czy model ten ewoluuje w kierunku modelu uczelni tzw. trzeciej generacji. Do cech charakteryzujących ten model należy dywersyfikacja źródeł finansowania oraz zwiększający się zakres związków z otoczeniem, zarówno w wymiarze edukacyjnym, jak i badawczym. Dlatego Autorka przeanalizowała te dwa obszary aktywności szkół wyższych.

Metodologia. Dla realizacji celu badawczego przeprowadzono analizę źródeł prawnych oraz literatury przedmiotu, a także badania typu desk research, w których wykorzystano m.in. dane Głównego Urzędu Statystycznego.

Kluczowe wnioski. Przeprowadzona analiza wskazuje, że w badanym okresie model szkół wyższych w Polsce ewoluował w kierunku modelu tzw. uczelni trzeciej generacji.

Słowa kluczowe: szkolnictwo wyższe w Polsce, szkoły wyższe, zarządzanie szkołami wyższymi, model uczelni trzeciej generacji 